\title{
Heaven on Earth. A Journal Through Shari'a Law from the Deserts of Ancient Arabia to the Streets of the Modern Muslim World. By Sadakat Kadri. New York, N.Y.: Farrar, Strauss and Giroux, 2012.
}

Sheldon Greaves

Henley-Putnam University

Follow this and additional works at: https://digitalcommons.usf.edu/jss

pp. $123-126$

\section{Recommended Citation}

Greaves, Sheldon. "Heaven on Earth. A Journal Through Shari'a Law from the Deserts of Ancient Arabia to the Streets of the Modern Muslim World. By Sadakat Kadri. New York, N.Y.: Farrar, Strauss and Giroux, 2012.." Journal of Strategic Security 5, no. 4 (2012) : 123-126.

DOI: http://dx.doi.org/10.5038/1944-0472.5.4.9

Available at: https://digitalcommons.usf.edu/jss/vol5/iss4/3

This Book Review is brought to you for free and open access by the Open Access Journals at Digital Commons @ University of South Florida. It has been accepted for inclusion in Journal of Strategic Security by an authorized editor of Digital Commons @ University of South Florida. For more information, please contact digitalcommons@usf.edu. 
Heaven on Earth. A Journal Through Shari'a Law from the Deserts of Ancient Arabia to the Streets of the Modern Muslim World. By Sadakat Kadri. New York, N.Y.: Farrar, Strauss and Giroux, 2012. 
Heaven on Earth. A Journal Through Shari'a Law from the Deserts of Ancient Arabia to the Streets of the Modern Muslim World. By Sadakat Kadri. New York, N.Y.: Farrar, Strauss and Giroux, 2012. ISBN 978-0-374-16872-8. Bibliography. Notes. Index. Pp. 372. \$28.00.

Shar'ia law has always been an esoteric subject in the West, but the events subsequent to 9/11 have not thrust it to the forefront, they have rendered it even more obscure. Sadakat Kadri provides a welcome antidote to this problem with his new book. Kadri brings a very impressive set of credentials to the task. He is both a practicing English barrister and a licensed New York attorney. In addition to being a practicing Muslim, he is also a gifted, award-winning travel writer with a gift for writing lively, engaging prose that simultaneously enlightens and entertains.

Heaven on Earth begins with a brief history of the origins of Islam and the ministry of Muhammad and his first four successors. As histories of Islam go, this one covers the subject in just enough detail to provide context to explain the difficulties faced by early Muslims as the religion grew from a regional belief system to an international power. Kadri points out a theme that recurs for much of the rest of the book, which is that while the Quran forms the nucleus of the Muslim faith, its guidance on law and jurisprudence address a particular time, place, and context, namely a desert culture that valued egalitarianism and preferred to deal with conflicts and offenses through reconciliation. As an example, Kadri notes that in the entire Quran there are only four crimes for which a punishment is even mentioned. Of the two capital offenses given, in both cases the death penalty is optional.

Kadri traces efforts by Muslim scholars to adapt the divine law of the Quran to a rapidly changing and increasingly sophisticated society. We see the deep unease with which these early scholars found themselves in a position where they had to, as they saw it, sit in the place of God in judging their fellows. Even though jurists and judges gradually became used to the idea, Kadri shows his readers the development of a legal system that was very reluctant to impose harsh penalties, preferring instead to seek repentance or reconciliation. 
A useful example of this aversion concerns the crime of adultery, for which the Quran allowed the penalty of death by stoning. Kadri shows how the legal systems went to extraordinary, even absurd lengths to avoid imposing this sentence, to the point that in the entire 500-year history of the Ottoman Empire, the penalty of stoning was imposed exactly once. In Syria its use is only recorded once. It was for a Christian missionary who was stoned to death under Roman law, three hundred years before Muhammad was born. To accomplish this, jurists would resort to remarkable flights of logic. For example, citing tales of Muslim mystics or accounts from Hadiths (traditional stories from the life of the Prophet), jurists decided that the period of human gestation could last as long as seven years. This offered them an exit should a woman whose husband had been away on a long journey suddenly become pregnant. Likewise, the infamous rule that four male witnesses were needed to prove illicit sexual intercourse was not originally written to make it impossible to convict rapists, but to protect women from specious accusations of adultery.

Kadri takes us through the development of the four main schools of Sunni jurisprudence and the Shi'a legal tradition, each one focused on a different method for arriving at legal decisions. He describes the difficulties of taking a legal code that was almost completely oral in transmission and committing it to written form, something that flew in the face of stronglyheld beliefs and traditions. At each step, we see how the legal code had to find its way through efforts to manipulate and dilute it, such as the struggle to identify a body of legitimate Hadiths with reliable sourcing.

A major crisis in the history of Islam was the loss of the caliphate following the destruction of Baghdad by the Mongols in 1258. Several major developments came out of this event. The first was the problem of succession that would eventually fall to the Ottomans. But a thornier problem concerned how to deal with a stronger infidel foe, and later how to do battle with this foe in later years when some of its members were Muslim, albeit of a variety not entirely recognizable. The problem was confronted by Ahmed ibn-Taymiyyah, who first experienced the Mongol threat as a six-year old refugee.

As simultaneously one of the most revered and reviled of medieval Muslim jurists, ibn-Taymiyyah developed a form of jurisprudence that was both subtle and unsparing. His primary contribution was to reject many of the regular sources of legal insight, Hadiths, analogical logic, scholarly consensus, and so forth. Instead he looked to the practices of the first three generations of Muslims for guidance. Ibn-Taymiyyah took this little-known tradition of looking to the ancestors (salafs) and built it into a legal theory known today as salafism. Because the work of ibn-Taymiyyah 
has such profound consequences for the current upheavals in Muslim countries, Kadri spends a good deal of time on ibn-Taymiyyah and his successors. It is time well-spent. Out of several accounts of this jurist and his work that I have read, Kadri's is one of the clearest and most informative.

The latter portion of the book starts with another, quieter cataclysm, namely the abolition of the Ottoman caliphate in 1920. With the loss of this touchstone of Muslim governance, however weak or inept, a vacuum opened up into which national leaders of Muslim countries failed to move. The Soviet invasion of Afghanistan created a major crisis within the Muslim world. If ever there was a cause that cried out for a declaration of jihad by the proper authorities, this was it. However, when national leaders failed to do so, others stepped into fill the void. From this and other factors came much of the radicalization of Islam that the world is contending with to this day.

Kadri's discussion of the current situation emphasizes that the emerging salafist and Islamist forms of jurisprudence has none of the sense of tolerance or unwillingness to exercise compulsion in matters of religion. Instead, the push for harsh penalties forms a grotesque caricature of traditional Muslim criminal law. While many Muslim countries still have brave judges and jurists who routinely commute or toss out death or amputation penalties imposed by their more zealous brethren, Kadri sees the trend in which the extremists are exerting their power to make executions and mutilations the norm instead of the very rare exception. Meanwhile extra-judicial "honor killings" and "traditionalists" such as the Taliban take shar'ia to a dark, uncompromising place. Kadri makes it clear that the fight is not over by any means, and that there are still many Muslims who abhor and detest the thinking of the newer, angrier generation of extremists.

One warning to potential readers of this book is that one will discover the ludicrous depths to which the debate surrounding shar'ia law has fallen in the United States. Thankfully, Kadri only spends a few pages near the end of the book on such specific controversies as state legislation banning shar'ia law, but in those brief pages he skillfully and completely demolishes many popular canards about shar'ia as a "threat to the Constitution," pointing out meanwhile (among other things) that federal arbitration law has allowed and positively encouraged the use of shar'ia in settling disputes among Muslims since 1925. 
Journal of Strategic Security

For someone who is new both to shar'ia and to Islam itself, Heaven on Earth is an excellent introduction, filled with wonderful insights and spiced with memorable anecdotes. Sadakat Kadri's work does much to dispel the obscurity surrounding this murky but important topic in national and global politics. It should do much to move this very important discussion in more fruitful directions.

Sheldon Greaves, Henley-Putnam University 